\begin{tabular}{|c|c|}
\hline \multirow{3}{*}{ 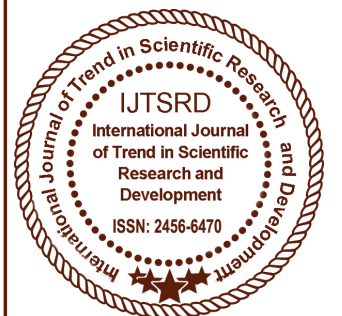 } & $\begin{array}{l}\text { International Journal of Trend in Scientific } \\
\text { Research and Development (IJTSRD) }\end{array}$ \\
\hline & International Open Access Journal \\
\hline & ISSN No: 2456 - 6470 | www.ijtsrd.com | Volume - 2 | Issue - 5 \\
\hline
\end{tabular}

\title{
An Analysis on Working Capital and its Impact on Sales and Profitability, with Special Reference to Niva Holdings, Minsk, Belarus
}

\author{
Ms. Sindhu S Shastry ${ }^{1}$, Mrs. Charithra $\mathrm{C} \mathrm{M}^{2}$, Dr Bhavya Vikas ${ }^{3}$ \\ ${ }^{1}$ Management Student, ${ }^{2}$ Assistant Professor, ${ }^{3}$ Associate Professor \\ BNMIT, Bangalore, Karnataka, India
}

\section{ABSTRACT}

The Paper titled "A Study on Working Capital Management and establishment of its impact on Sales and Profitability" is an effort to analyse the financial statements of Niva Holdings Ltd., Belarus, Minsk. The study is conducted at a Heavy Equipment Manufacturing Industry. "NIVA-Holding" is the leader of Belarusian mining machinery manufacturers. Tools used in the study are Ratio Analysis \& Regression to understand the trend of working capital and also establish a relationship by arriving at an equation. Major finding of the study was that the company has been seeing a wavy trend with respect to its ratios. A relationship has been established between Working Capital \& Sales and Working Capital \& Profits of the business, using Regression.

KEYWORD: Working Capital, Finance, Liquidity, Sales, Profit

\section{INTRODUCTION}

Finance deals with the learning of savings. Finance covers the changing aspects of possessions and obligations for a period under conditions of many steps of fears and hazards. Finance explains the science of money administration. Marketing members aims to meet the value resources built on their level of risk, essential value, and their expected percentage of return. Finance can be categorised into public, corporate and personal finance. Financial management describes the effective and operative administration of currency in such a way that achieve the of the objectives of company. It has the specified functions that is directly related with the high-level administration.

\section{Working Capital}

Working capital is a term that defines working fluidity of business. It secures fixed assets like firm and resources; working capital is also considered a part of operating capital. Gross working capital equals current assets. If the gap between the current assets and current liabilities is too wide, it is known as a deficit situation. It can be calculated using the following equation: Working Capital = Current Assets - Current Liabilities.

Current assets and current liabilities consists of three accounts namely, receivables, inventory and payables.

\section{Objectives of Working Capital}

$>$ Ensuring the organisation has enough cash to meet its immediate obligations

Arranging funds to be available at the right point of time and right from the right source.

$>$ Forecasting and planning of future requirements.

\section{RESEARCH METHODOLOGY}

Statement of the Problem:

"Study of Working Capital Management at Niva Holdings Ltd, Minsk, Belarus"

\section{Need for the study:}

To analyse the financial health and operational success of Niva Holdings Ltd, Minsk, Belarus.

\section{Objectives:}

$>$ To understand the WC position of the organisation

$>$ To establish a relationship between working capital and sales

$>$ To establish a relationship between working capital and profitability 


\section{Scope of the study:}

The scope of the study is limited to Niva Holdings, Minsk, Belarus.

\section{Research Methodology}

Data Source: Secondary Data

$>$ Data is collected from articles on Working Capital Management.

$>$ Data is also collected from the employees working in Niva Holding and from their financial statements.

\section{Data Period:}

Financial Year 2014-2015, 2015-2016 and 20162017.

\section{Data Analysis:}

Quantitative research hence, there is negligible use of primary data. Analysis of the data is done using ratios and regression.

\section{Limitations}

$>$ No past data available on study of Working Capital Management in the Republic of Belarus.

$>$ Access to many financial data was restricted.

\section{Literature Review}

Fluidity and efficiency of position for the business is not reasonable and desirable to be supported in direction to be able to encounter its responsibilities in time were observed in studies made Madhavi K. (2014) and Joseph (2014) in their papers. Similar observations we made by Durga (2015) that the performance of sales has remained good over the years however, the annual growth rate has seen a downward trend when a relation between working capital and sales and profit was established.

\section{ANALYSIS AND INTERPRETATION $>$ Net working capital}

\section{Graph Showing Net working capital}

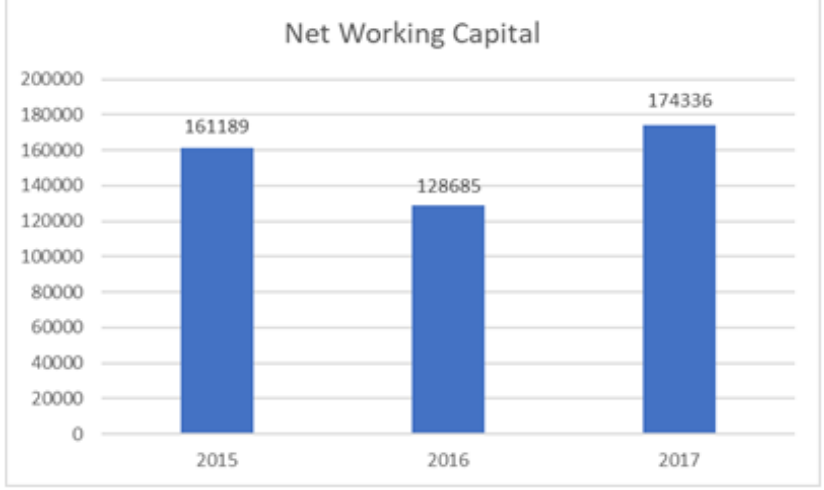

\section{Interpretation}

$>$ Net working capital measures the business's possible reserve of funds.

Niva Holdings has a higher NWC which indicates that the company has a greater potential to meet its current obligations

Networking Capital Ratio

\section{Graph Showing Net working capital ratio}

\section{Net Working Capital Ratio}

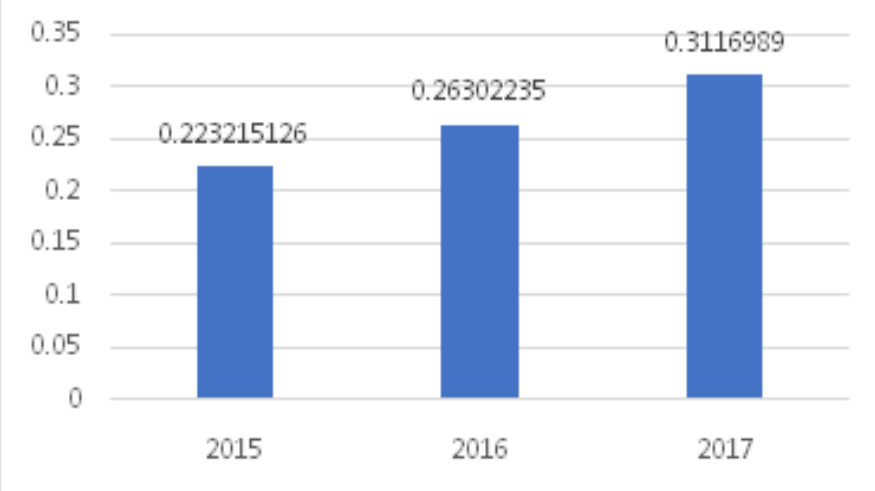

\section{Interpretation}

D A company having a higher NWC ratio has a greater ability to meet its current obligations.

The Net Working Capital of the Company has seen a wavy trend in the last 3 financial years.

\section{Current Ratio}

Graph Showing Current Ratio

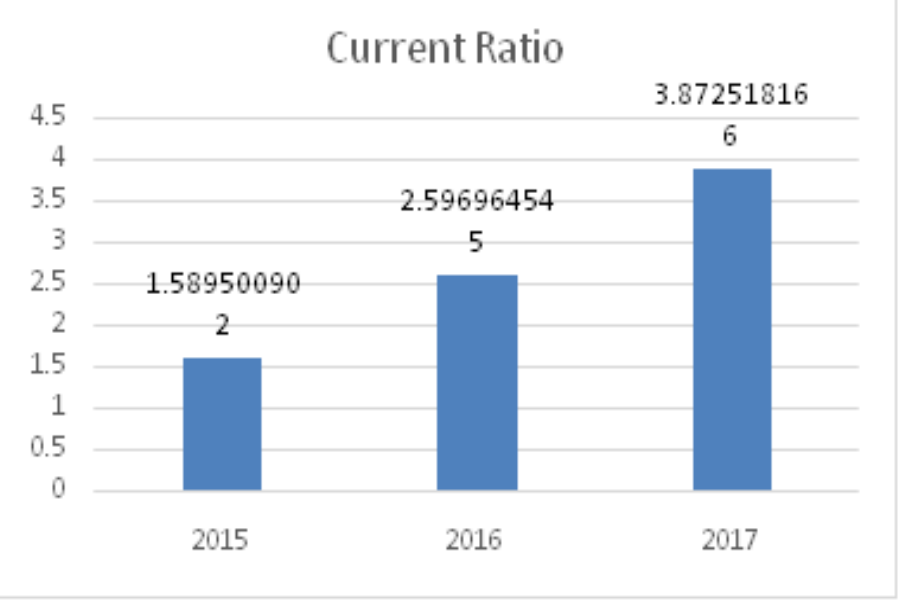

\section{Interpretation}

$>$ The above graph depicts that the current ratio of Niva holdings for the last three financial years.

$>$ The ideal ratio is $2: 1$, in all the years except the year 2015 the ratio is more than 2:1 and we can depict that the liquidity position of Niva Holdings is favourable.

$>$ Quick Ratio 
International Journal of Trend in Scientific Research and Development (IJTSRD) ISSN: 2456-6470

Graph Showing Quick Ratio

\section{Quick Ratio}

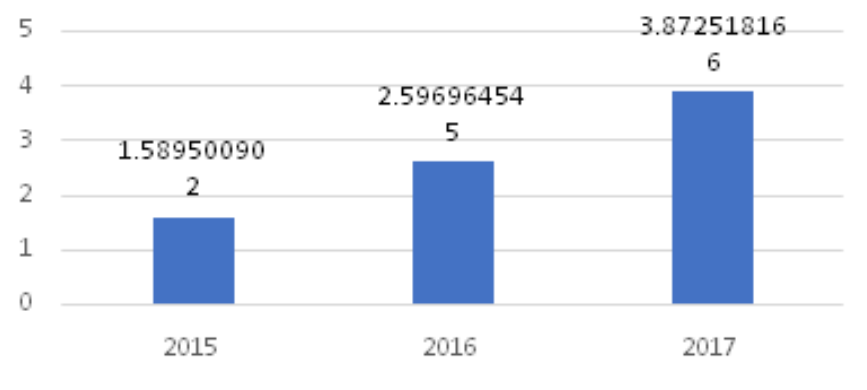

\section{Interpretation:}

$>$ The Ideal ratio is 1:1 which indicates that the firm is able to quickly meet its obligations.

From the above graph it can be interpreted that over the year Niva Holdings has done exceptionally well.

$>$ Inventory turnover ratio

\section{Graph Showing Inventory Turnover Ratio}

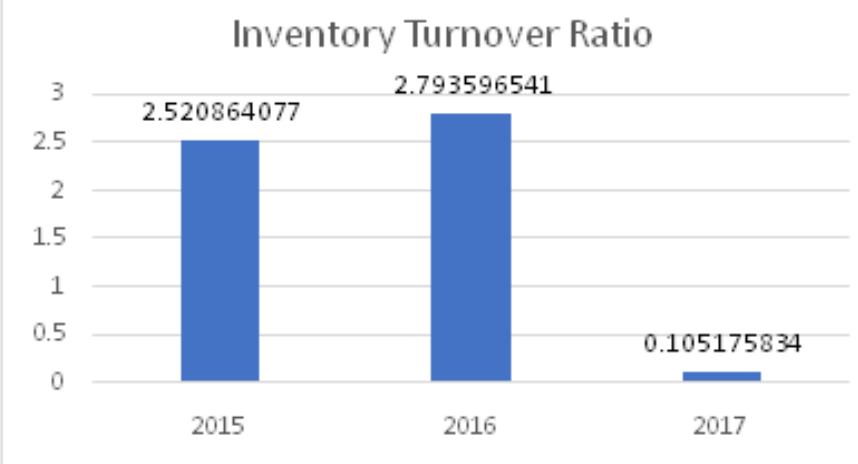

\section{Interpretation:}

$>$ From the above graph it can be noted that the firm has been efficient with respect to converting its inventory into sales.

$>$ In the year 2015 and 2016 however it has seen a drastic fall in 2017 which shows no efficiency.

$>$ Debtors Turnover Ratio

\section{Graph Showing Debtors Turnover Ratio}

Debtors Turnover Ratio

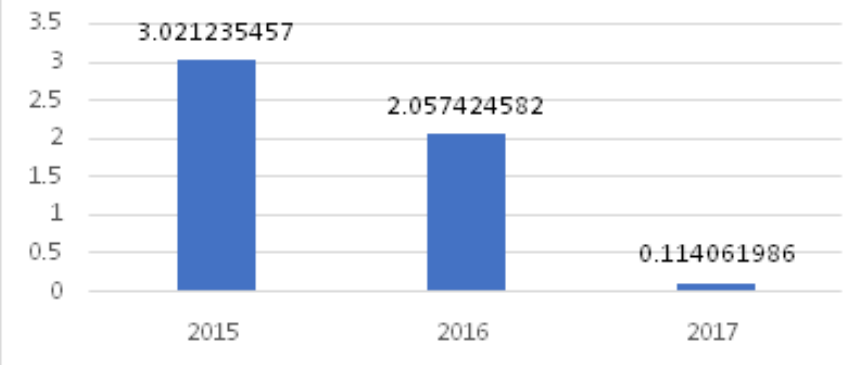

\section{Interpretation}

$>$ From the above graph it is noted that debtors have been paying the company on time in the years 2015 and 2016. It has however seen a lag in 2017. Creditors Turnover Ratio

\section{Graph 4.7 - Showing Creditors Turnover Ratio}

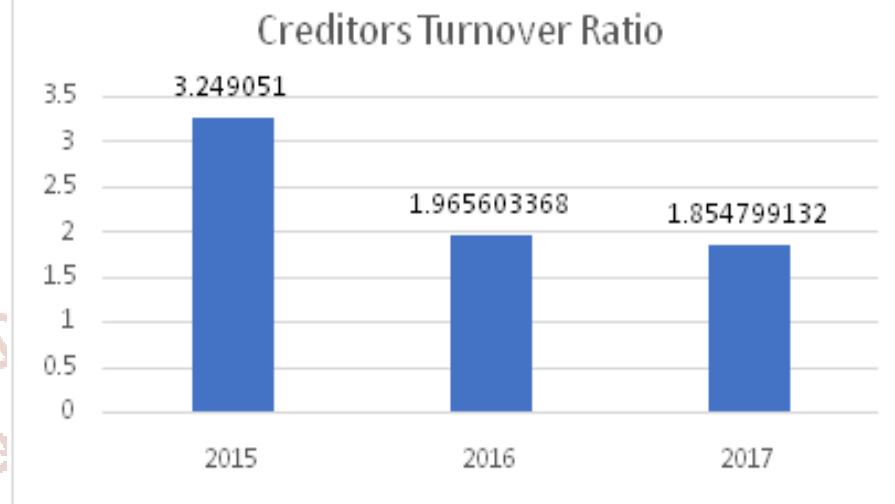

\section{Interpretation}

$>$ From the above graph it can be noted that the creditors are been paid on time and the company has a good credit worthiness.

It can also be interpreted that the company is not making use of given credit facility.

Working Capital Turnover Ratio

\section{Graph4.8 - Showing Working Capital Turnover Ratio}

\section{Working Capital Turnover Ratio}

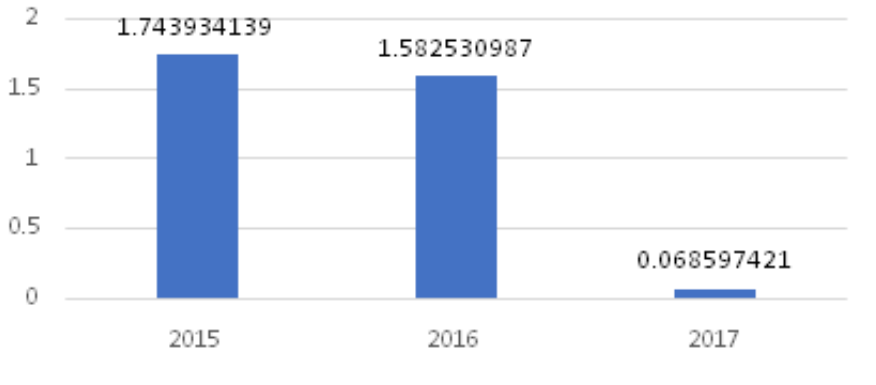

\section{Interpretation}

$>$ The above graph depicts that the Niva Holdings has maintained a good working capital turnover ratio meaning that it has sufficient funds to run the operations of the business for the year 2015 and 2016.

However, its position seems dangerous in 2017.

$>$ Working Capital to Net Worth Ratio 
International Journal of Trend in Scientific Research and Development (IJTSRD) ISSN: 2456-6470

\section{Graph 4.9 - Showing Working Capital to Net worth Ratio}

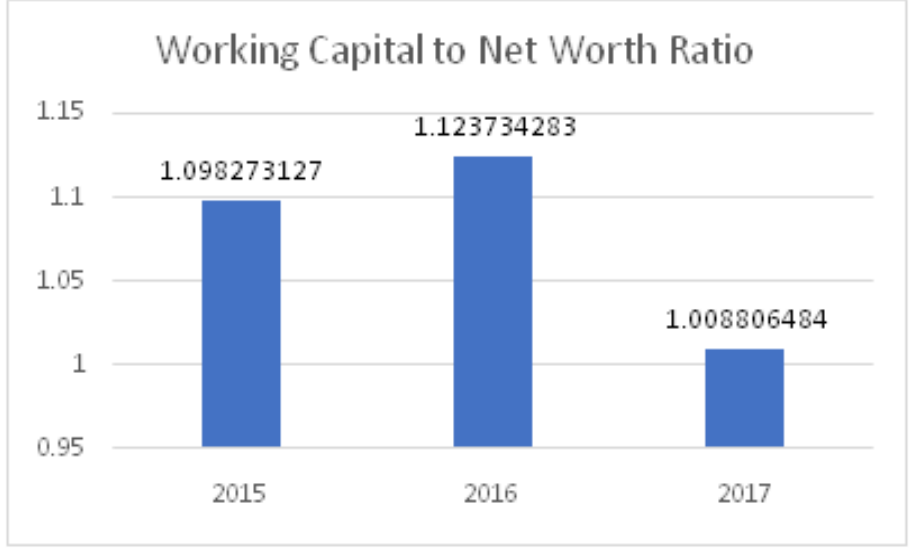

\section{Interpretation}

$>$ The relationship with the shareholders seems healthy in the year 2015 and 2016.

In the year 2017 the relationship doesn't seem as smooth.

1. Working Capital \& Sales Regression Analysis

\begin{tabular}{|c|c|c|c|c|c|}
\hline Sl. No & Year & $\begin{array}{c}\text { Sales } \\
(\mathrm{x})\end{array}$ & $\begin{array}{l}\text { Working Capital } \\
\text { (y) }\end{array}$ & $\begin{array}{l}\text { Product of Sales and Working } \\
\text { Capital }\left(\mathrm{x}^{*} \mathrm{y}\right)\end{array}$ & $\begin{array}{c}\text { Square of sales } \\
\left(x^{2}\right)\end{array}$ \\
\hline 1 & 2015 & 281103 & 161189 & 45310711467 & 79018896609 \\
\hline 2 & 2016 & 203648 & 128685 & 26206442880 & 41472507904 \\
\hline 3 & 2017 & 11959 & 174336 & 2084884224 & 143017681 \\
\hline Gross Total & 3 & 496710 & 464210 & 73602038571 & 120634422200 \\
\hline Denotation & $\mathrm{N}$ & $\Sigma \mathrm{x}$ & Ofy & 1 Scientili $\Sigma x y$ & $\Sigma \mathrm{x}^{2}$ \\
\hline
\end{tabular}

\begin{tabular}{|c|c|}
\hline Formula $=\Sigma y=n a+b \Sigma x$ & Formula $=\Sigma x y=a \Sigma_{x}+b \Sigma_{x}{ }^{2}$ \\
\hline By replacing the formula with values & By replacing the formula with values \\
\hline $464210=3 a+496710 b$ & $7360203851=496710 a+120634422200 b$ \\
\hline Multiply by 496710 & Multiply by 3 \\
\hline $\begin{array}{c}230577749100=1490130 \mathrm{a}+246720824100 \mathrm{~b} \\
---\mathrm{Eq} 1\end{array}$ & $\begin{array}{c}22080611553=1490130 \mathrm{a}+361903266600 \mathrm{~b} \\
--\mathrm{Eq} 2\end{array}$ \\
\hline Subtract Eq 2 from Eq 1 we get: & \\
\hline $208497137500=0-115182442500 \mathrm{~b}$ & 3 \\
\hline $\mathrm{b}=208497137500 / 115182442500=1.8101$ & \\
\hline $\begin{array}{c}\text { Now, replacing } b=1.8101 \text { in Eq } 1 \\
\text { i.e. } 464210=3 a+496710(1.8101) \\
\begin{array}{c}464210=3 a+899094.771 \\
-3 a=434884.771 \\
a=-144961.59\end{array}\end{array}$ & \\
\hline
\end{tabular}

Working Capital $(y)=-144961.59+1.8101$ Sales $(x)$

The above equations can be used to forecast working capital (dependent variable) by use of sales (independent variable) 
International Journal of Trend in Scientific Research and Development (IJTSRD) ISSN: 2456-6470

2. Working Capital \& Profit Regression Analysis

\begin{tabular}{|c|c|c|c|c|c|}
\hline SI. No & Year & $\begin{array}{c}\text { Profit } \\
(\mathbf{x})\end{array}$ & $\begin{array}{c}\text { Working Capital } \\
(\mathbf{y})\end{array}$ & $\begin{array}{c}\text { Product of Profit and Working } \\
\text { Capital }\left(\mathbf{x}^{*} \mathbf{y}\right)\end{array}$ & $\begin{array}{c}\text { Square of Profits } \\
\left(\mathbf{x}^{2}\right)\end{array}$ \\
\hline 1 & 2015 & 23167 & 161189 & 3734265563 & 536709889 \\
\hline 2 & 2016 & -42783 & 128685 & -5505530355 & 1830385089 \\
\hline 3 & 2017 & 420 & 174336 & 73221120 & 176400 \\
\hline Gross Total & 3 & -19196 & 464210 & -1698043672 & 2367271378 \\
\hline Denotation & $\mathrm{N}$ & $\Sigma \mathrm{x}$ & $\Sigma \mathrm{y}$ & $\Sigma \mathrm{xy}$ & $\Sigma \mathrm{x}^{2}$ \\
\hline
\end{tabular}

\begin{tabular}{|c|c|}
\hline Formula $=\Sigma \mathbf{y}=\mathbf{n a}+\mathbf{b} \Sigma_{\mathbf{x}}$ & Formula $=\Sigma x y=a \Sigma x+b x^{2}$ \\
\hline By replacing the formula with values & By replacing the formula with values \\
\hline $464210=3 a-19196 b$ & $(1698043672)=(19196) a+2367271378 b$ \\
\hline Multiply by (19196) & Multipl \\
\hline$(8910975160)=(57588) a+368486416 b$ & $5094131016=575$ \\
\hline Subtract Eq 1 from Eq 2 we get: & \\
\hline $140051061800=0+673332770 b$ & \\
\hline $\mathrm{b}=140051061800 / 673332770 ; \mathrm{b}=207.99$ & \\
\hline $\begin{array}{l}\text { Now, replacing } \mathrm{b}=207.99 \text { in Eq } 1 \\
\text { i.e. } 464210=3 \mathrm{a}-19196(207.99) \\
\begin{aligned} & 464210=3 \mathrm{a}-3992576.04 \\
&-3 \mathrm{a}=3528366.04 \\
& \mathrm{a}=-1176122.013\end{aligned}\end{array}$ & $\begin{array}{l}\text { al wournal } \\
\text { scientific }\end{array}$ \\
\hline
\end{tabular}

Working Capital $(y)=-1176122.013+207.99$ Profit $(x)$

The above equation can be used to forecast working capital (dependent variable) by use of profit (independent variable).

\section{Findings}

$>$ Niva Holdings has a higher NWC which indicates that the company has a greater potential to meet its current obligations as seen from the calculations.

$>$ The liquidity position of Niva Holdings is favourable as their liquid ratio.

$>$ The relationship with the shareholders seems healthy as they are paying off their shareholders on time.

$>$ The company is not making use of given credit facility as they have been consistent in paying off their creditors on time.

$>$ A relationship has been established between Working capital and Sales using he following equation: Working Capital $(\mathrm{y})=-144961.59+$ 1.8101 Sales (x).

$>$ A relationship has been established between Working capital and Profit using he following equation: Working Capital $(\mathrm{y})=-1176122.013+$ 207.99 Profit (x).

\section{Suggestions}

> The company can consider making optimal use of the credit facility available as they have been paying their creditors on time.

> The company can also increase the Debtors for contingency in case there are any financial emergency in the future.

Avoiding of high liquidity in the operations is recommended as there might me high cash outflows and liquidity does not earn any return to the firm.

\section{Conclusion:}

The study has been helpful to understand the Working Capital Management. The organisation has seen an inconsistent trend with respect to its working capital management. The trends wobble between the extremes of financial stability. Major finding of the study was that the company has been seeing a wavy trend with respect to its ratios. The study has also revolved around establishing a relationship between 
Working Capital \& Sales also Working Capital \& Profit of the organisation.

\section{BIBLIOGRAPHY}

\section{Reference Articles:}

1. Dr.T.Durga Prasad (2015),Working Capital Management with Regression Analysis (With reference to Visakhapatnam Steel Plant (RINL), VSP), Volume 3, Issue 8, ISSN 2349-4476

2. Jisha Joseph, (2014), Impact of Working Capital Management on Firm "s Profitability and
Liquidity: An Empirical Study of Ashok Leyland Ltd., International Journal of Research in Commerce and Management, Vol. 5, No. 2, pp. 32-38

3. Madhavi K., (2014), Working Capital Management of Paper Mills, International Journal of Research in Business Management, Vol. 2, No. 3, pp. 63-71

Webliography:

en.niva.by

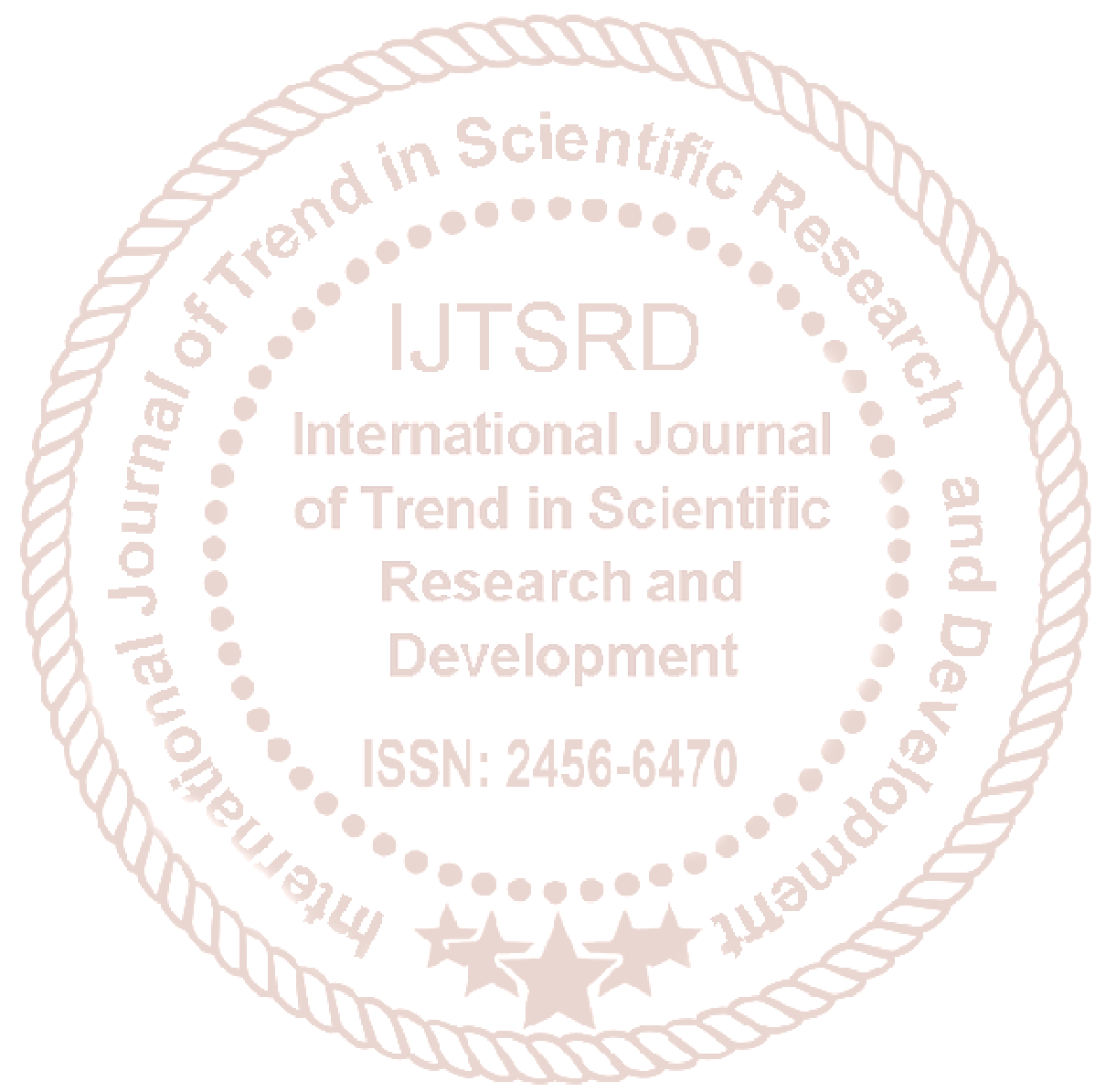

